\title{
KEPEMIMPINAN PEREMPUAN DALAM MENINGKATKAN KINERJA ORGANISASI PADA KOPRI (KORPS PMII PUTRI) WILAYAH LAMPUNG
}

\author{
Siti Wuriyan \\ Universitas Islam Negeri (UIN) Raden Intan Lampung \\ Jl. Letnan Kolonel H. Endro Suratmin, Sukarame, Bandar Lampung, Lampung 35131 \\ s.wuryan@yahoo.com
}

\begin{abstract}
Leadership is the power of leaders to invite, influence, and move others to do something, in order to achieve effective and efficient goals in an organization. KOPRI is short for Putri PMII Corps, which is part of the PMII organization which is semi-autonomous, with the meaning "semi" there is a line of instructions, consultation and coordination. The meaning of "autonomous" is that KOPRI has the duties and authority in accordance with their fields in accordance with household regulations, and in charge of empowering both members and cadres of PMII women. In this study the authors specialize in the management of the KOPRI Lampung Region which addresses at Jalan Pahlawan Gang Cempaka, Number 40 Kedaton District, Bandarlampung City. Women's leadership in improving organizational performance in KOPRI Lampung Region, the authors can conclude. The type of leadership used by the KOPRI Lampung Region is the type of democratic leadership, it can be seen that each will plan or determine decisions or policies always prioritize deliberation, and does not rule out arguments from members into decisions agreed upon by the organization. The implementation of activities in KOPRI generally provides significant benefits for members even if they are not going well. Members can increase their capabilities with women's activities.
\end{abstract}

Keywords: Leadership, Women, Organizational Performance, KOPRI

\begin{abstract}
ABSTRAK
Kepemimpinan adalah kekuasaan pemimpin untuk mengajak, mempengaruhi, dan menggerakan orang lain untuk melakukan sesuatu, demi mencapai tujuan yang efektif dan efesien dalam suatu organisasi. KOPRI merupakan kependekan dari Korps PMII Putri, yang merupakan bagian dari organisasi PMII bersifat semi otonom, dengan mengandung makna "semi" terdapat garis intruksi, konsultasi dan koordinasi. Adapun makna "otonom" adalah KOPRI mempunyai tugas dan wewenang sesuai dengan bidangnya sesuai dengan peraturan rumah tangga, dan yang membidangi pemberdayaan baik anggota maupun kader perempuan PMII. Dalam penelitian ini penulis mengkhususkan pada kepengurusan KOPRI Wilayah Lampung yang beralamatkan di Jalan Pahlawan Gang Cempaka, Nomor 40 Kecamatan Kedaton Kota Bandarlampung. Kepemimpinan perempuan dalam penigkatan kinerja organisasi pada KOPRI Wilayah Lampung, maka penulis dapat menyimpulkan. Tipe kepemimpinan yang digunakan oleh KOPRI Wilayah Lampung ialah tipe kepemimpinan demokratik, hal ini dapat diketahui bahwa setiap akan merencanakan maupun menetapkan keputusan atau kebijakan selalu mengedepankan musyawarah, serta tidak menutupkemungkinan argumentasi dari anggota menjadi keputusan yang disepakati oleh organisasi. Pelaksanaan kegiatan di KOPRI secara umum memberikan manfaat yang berarti bagi anggota walaupun tidak berjalan dengan baik. Anggota dapat meningkatkan kapabilitas mereka dengan adanya kegiatan keperempuanan.
\end{abstract}

Kata Kunci : Kepemimpinan, Perempuan, Kinerja Organisasi, KOPRI 


\section{Pendahuluan}

Masih terdapat silang pendapat dikalangan ahli, terutama ahli hukum Islam tentang kepemimpinan perempuan. Sudah menjadi kenyataan sosial di banyak negara, perempuan sudah diterima menempati jabatan-jabatan publik. Untuk menyebut beberapa nama, saat ini Menteri Luar Negeri Amerika Serikat, Hillary Clinton, adalah seorang wanita. Begitu pula, mantan Perdana Menter Inggris, Margareth Thatcher, mantan Perdana Menteri Pakistan, Benazir Butho, di Negara Indonesia sendiri pernah seorang wanita memimpin negeri ini, yakni Mega Wati Soekarno Putri, dengan melihat kader KOPRI sudah menyebar keseluruh Indonesia. serta sejumlah tokoh perempuan mantan ketua umum KOPRI Lampung periode 1992-1994 yakni Dra. Jauharoh Haddad, M.M Ketua Partai Politik , Erlina, S.P menduduki sebagai Ketua KPU Kota Bandar Lampung, Hj. Rini Setiawati, S.Ag., M.Sos.I yang melakukan gerakanya di Akademisi sebagai Dosen Fakultas Dakwah sekaligus Pembantu Dekan III Fakultas Dakwah IAIN Lampung. Serta Khalida, S.H yang berperan di Komisi Informasi Provinsi Lampung, dan Fatikhatul Khoiriyah, S.H.I,. M.H dengan umur yang sangat muda merupakan kader Kopri yang menjadi Komisioner Badan Pengawasan Pemilu Lampung. Serta masih banyak lagi Kader Kopri yang menduduki jabatan apapun baik di eksekutif, legislatif maupun yudikatif dan segala bidang pekerjaan lainya.. Mereka semua adalah perempuan-perempuan yang memegang posisi sebagai pemimpin di lingkungan dan wilayahnya masingmasing. Belum lagi mereka yang menempati posisi pimpinan di dunia bisnia, LSM, ormas, dunia pendidikan, dan sebagainya.

Sistem dan praktek sosial, baik bercorak religious maupun sekuler, disusun berdasarkan asas patriarkhi, yang menjadikan laki-laki sebagai pusat sedangkan perempuan sebagai sub ordinat. Sistem patriarkhi ini biasanya membuat pembagian tugas: laki-laki bertugas menangani urusan-urusan depannya itu mencari nafkah, melakukan pekerjaan-pekerjaan berat dan bertanggungjawab atas kelangsungan keluarga, kelompok, maupun negara, sedangkan perempuan ditugaskan menangani uusan-urusan belakang yaitu sebagai isteri penenang dan pelayan suami, ibu yang malahirkan, mengasuh dan mendidik anak, menjaga harta benda suami, dan membina etika keluarga. Dengan demikian sulit diakui kemampuan dan eksistensi serta aktualisasi dirinya dalam bidang sosial, yang dianggap bukan lahannya. Hal demikian menimbulkan banyak orang yang tidak memposisikan perempuan sebagai pemimpin dalam bidang social, politik, dan bisnis.

Hadirnya Islam sebagai penuntun, pembawa kabar gembira, dan pemberi peringatan bagi manusia, membuat pandangan terhadap perempuan berubah, harkat pun naik, tindak penindasan serta kesewenang-wenangan pun lenyap. Islam mendeklarasikan laki-laki dan perempuan senantiasa berkedudukan sama, tidak kurang tidak lebih, sebab keduanya diciptakn dari jiwa yang tunggal.

Seperti firman Allah SWT. dalam QS. An-Nisa: 1 berikut ini:

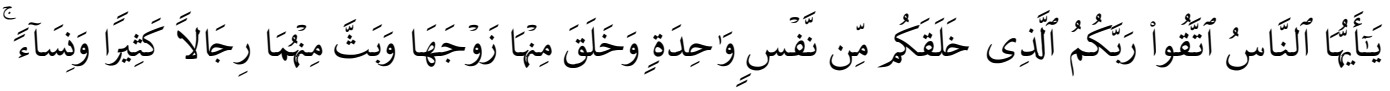

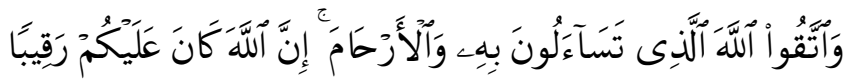

Artinya : "Hai sekalian manusia, bertakwalah kepada Tuhan-mu yang Telah menciptakan kamu dari seorang diri, dan dari padanya Allah menciptakan isterinya; dan dari pada keduanya Allah memperkembang biakkan laki-laki dan perempuan yang banyak. dan bertakwalah kepada Allah yang dengan (mempergunakan) nama-Nya kamu saling meminta 
satu sama lain, dan (peliharalah) hubungan silaturrahim. Sesungguhnya Allah selalu menjaga dan Mengawasi kamu." (Q.S. An-Nisa: 1)

Firman Allah SWT. juga dalam Q.S. Al-Hujuraat:13 berikut ini:

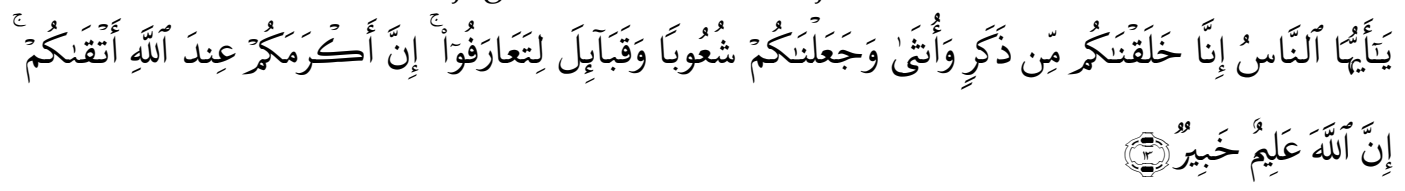

Artinya : "Hai manusia, Sesungguhnya kami menciptakan kamu dari seorang lakilaki dan seorang perempuan dan menjadikan kamu berbangsa-bangsa dan bersuku-suku supaya kamu saling kenal-mengenal. Sesungguhnya orang yang paling mulia diantara kamu disisi Allah ialah orang yang paling taqwa diantara kamu. Sesungguhnya Allah Maha mengetahui lagi Maha Mengenal." (Q.S. Al-Hujuraat: 13)²

Ayat-ayat diatas menunjukkan bahwa tidak ada perbedaan antara laki-laki dan perempuan, sebab sebagian mereka berasal dari sebagian yang lain, laki-laki dari perempuan dan peremupan dari laki-laki. Kedudukan laki-laki dan perempuan sama dimata Allah SWT., tetapi hanya keimanan dan ketaqwaannyalah yang membedakan keduanya, selain itu juga laki-laki dan perempuan diciptakan oleh Allah untuk salinh mengenal satu sama lain serta untuk saling meningkatkan dan menjaga dari perbuatan-perbuatan yang melanggar hukum Allah SWT.

Islam memberikan kebebasan yang begitu besar kepada perempuan dalam memimpin, sehingga tidaklah mengherankan jika pada masa Nabi Muhammad SAW., ditemukan sejumlah perempuan yang memiliki kemampuan dan prestasi cemerlang yang dimiliki kaum laki-laki, seperti 'Aisyah mampu meriwayatkan 2210 Hadits dan mengalahkan kalangan sahabat Nabi yang laki-laki. ${ }^{3}$

Pada zaman Rasulullah SAW., kaum perempuan mengerjakan berbagai macam pekerjaan. Bahkan sebagian mereka turut serta dalam jihad di Jalan Allah SWT., dan ikut berperang. Banyak kaum perempuan yang ikut bersama Rasulullah SAW., dalam peperangan yang beliau pimpin langsung, seperti Nasibah binti Ka'bah ikut serta dalam Perang Uhud, Aminah binti Qays Al-Ghifariyah dan Ablat Bila' Husna ikut dalam Perang Khaybar, serta Ummu 'Athiyah Al-Ansharriyyah, AlRabi'ah binti Mas'ud, dan perempuan-perempuan lainnya ikut dalam berbagai perang membela Islam. ${ }^{4}$ Dalam jaminan Al-Qur'an, perempuan dengan leluasa memasuki semua sektor publik lainnya. Singkatnya, kepemimpinan perempuan telah menjadi kenyataan sejarah yang tak terbantahkan lagi.

Dalam konteks Indonesia, wacana kepemimpinan perempuan sesuai dengan isu gender dan pembangunan sudah menjadi projek dunia ketiga yang telah diadopsi oleh Indonesia. Paradigma tersebut telah mampu mengalahkan pola interaksi pemerintah dalam memaknai perempuan dalam pembangunan. Hal ini ditandai dengan hal yang signifikan suburnya lembaga-lembaga perempuan yang memfokuskan programnya pada pengkajian, pendidikan dan penelitian mengenai pemberdayaan perempuan dalam berbagai bidang. Dilingkungan ormas Islam seperti Nahdlatul'Ulama (NU), yang secara struktural dapat dirujuk pada keberadaan Muslimat dan Fatayat yang aktif memperjuangkan kesetaraan gender dalam Islam. Kemudian, ormas Islam lain seperti Muhammadiyah, kontribusi 'Aisiyah dan

\footnotetext{
1 Departemen Agama RI, Al-Qur'an dan Terjemahan, (Bandung: CV. Diponegoro, 2000), h. 61

2 Ibid, h. 376

${ }^{3}$ Abu Yasid, Fikih Politik, (Jakarta: Erlangga, 2005), h. 24

${ }^{4}$ Muhyidin Mas Rida, Wanita dalam Fikih Qardhawi, (Jakarta: Pustaka Al-Kautsar, 2009), h. 239
} 
Nasyi'atul 'Aisyiyah dalam peletakan awal keterlibatan kepemimpinan perempuan dalam kependidikan, sosial, kesehatan dan ruang-ruang publik lainya. Semangat meneguhkan pandangan bahwa terdapat akar kuat terlibatnya ormas Islam dalam mewujudkan keadilan dan kesetaraan gender di Indonesia. ${ }^{5}$

Bedasarkan kenyataan di atas, perbedaan fungsi biologis antara laki-laki dan perempuan tidak berarti membedakan status dan kedudukan yang setara antara keduanya dan dalam menentukan kualitas keagamaan, Islam tidak membedakan atas gender laki-laki dan perempuan, akan tetapi, ada sebagian kaum intelektual yang menyatakan bahwa apapun alasannya derajat kaum wanita tidak dapat disamakan dengan derajat laki-laki, apalagi masalah kepemimpinan.

Adanya ketidaksetaraan persamaan hak dan pandangan terhadap kaum perempuan diberbagai bidang telah ada, terutama dalam bidang kepemimpinan. Banyak yang menghubungkan antara kemampuan individu dalam memimpin dilihat dari segi biologis yang melekat pada diri sang pemimpin yaitu berdasarkan pada perbedaan jenis kelamin. Pada akhirnya mengakibatkan perspektif yang berbedabeda dalam menilai kepemimpinan perempuan dan laki-laki pada perusahaan atau organisasi.

Demikian pula yang diungkapkan oleh Kimbal Young dalam bukunya Kartini Kartono bahwa kepemimpinan adalah bentuk dominasi yang didasari atas kemampuan pribadi yang sanggup mendorong atau mengajak orang lain untuk melakukan sesuatu. Berdasarkan akseptasi/penerimaan oleh kelompoknya, dan memiliki keahlian khusus bagi situasi khusus. ${ }^{6}$

Berdasarkan referensi di atas bahwa seorang pemimpin dapat meningkatkan hasil yang lebih baik dari sebelumnya dan memiliki prestasi kerja yang lebih baik pula, sehingga seorang pemimpin perempuan akan diakui kepemimpinannya oleh bawahan maupun orang lain karena kemampuan memimpin yang baik untuk berhasilnya tujuan organsasi.

Hadirnya Korps Pergerakan Mahasiswa Islam Indonesia Putri (KOPRI) sebagai salah satu organisasi pemberdayaan mahasiswi, melakukan gerakan pemberdayaan perempuan yang benar-benar mampu menempatkan posisinya sebagai agen of change, agen perubahan. Perubahan ditingkatan nalar atau mindset maupun perubahan pada praksis gerakan yang nyata sehingga dapat menjadi sebuah sinergitas gerakan antara nalar dan prilaku hidup. ${ }^{7}$

Dalam perkembangannya KOPRI telah menunjukan eksistensinya diberbagai wilayah Indonesia. Hal ini ditandai dengan adanya kepengurusan ditingkatan provinsi, kabupaten atau kota, serta seluruh perguruan tinggi. Salah satunya ialah KOPRI Wilayah Lampung, yang beralamatkan di Jalan Cempaka, No. 40 Kecamatan Kedaton Kota Bandar Lampung. ${ }^{8}$ Tentunya sebagai organisasi pengkaderan mahasiswi, KOPRI juga perlu meningkatkan kinerja organisasi di tengah-tengah baik ditingkat regional maupun lokal.

Salah satu instrumen keorganisasian yang menjadi landasan dalam pencapaian tujuan organisasi ialah pengukuran kinerja organisasi. Pengukuran kinerja

${ }_{5}$ Arief Subhan, dkk., Citra Perempuan Dalam Ialam: Pandangan Ormas keagamaan, (Jakarta: PT. Gramedia Pustaka Utam,a, 2003), h. 5

${ }^{6}$ Kartini Kartono, op.cit., h. 27

7 Irma Muthoharoh (2011), Artikel KOPRI-PB.PMII Kawah Canra dimuka kepemimpinan Perempuan PMII,www.kopri.pmii.or.id/ (Accesed 01 april 2012)

8 Fitri Chindiathia, ketua umum KOPRI Wilayah Lampung, interview tanggal 02 April 2012 
dalam sebuah organisasi merupakan hal yang sangat penting untuk dilakukan karena semua organisasi sangat perlu mengevaluasi, dan merencanakan kinerjanya sehingga menjadi proses peningkatan kinerja. Selama ini implementasi pengukuran kinerjanya lebih banyak hanya dilakukan oleh organisasi profit seperti perusahaan swasta, BUMN, dibandingkan dengan organisasi non profit yang masih relatif sedikit dilakukan.9

KOPRI Wilayah lampung yang merupakan badan semi otonom dari PMII dan merupakan perpanjangan tangan dari pengurus besar KOPRI, harus mampu memberikan kontribusi terhadap kader atau anggota perempuan ditingkat provinsi, khusunya, masyarakat pada umumnya agar gerakan perempuan ditingkatan mahasiswi mengalami perubahan yng signifikan, atas dasar inilah penulis mengambil judul artikel "Kepemimpinan Perempuan dalam Peningkatan Kinerja Organisasi pada KOPRI Wilayah Lampung."

\section{Kepemimpinan}

Kepemimpinan adalah kemampuan seni atau teknik untuk membuat sebuah kelompok atau orang mengikuti dan mentaati segala keinginannya. Kepemimpinan hanya dapat dilaksanakan oleh seorang pemimpin. Seorang pemimpin adalah seseorang yang mempunyai keahlian memimpin, mempunyai kemampuan mempengaruhi pendirian/pendapat orang atau sekelompok orang tanpa menanyakan alasan-alasannya. Pemimpin adalah seseorang yang aktif membuat rencana-rencana, mengkoordinasi, melakukan percobaan dan memimpin pekerjaan untuk mencapai tujuan bersama-sama. ${ }^{10}$ Proses kepemimpinan menggambarkan asumsi bahwa kepemimpinan dihubungkan dengan proses mempengaruhi orang baik individu maupun masyarakat. Dalam hal ini, seorang pemimpin dengan sengaja mempengaruhi kepada orang lain dalam susunan aktivitasnya dan hubungan dalam kelompok atau organisasi.

Konsep-konsep kepemimpinan dan hubungannya dengan teori kepemimpinan yang dijadikan rujukan atau referensi kaum perempuan, yaitu beberapa tulisan para ilmuan dan beberapa pemaknaan teks Al-Qur'an maupun hadits Nabi SAW. Disamping itu, akan diuraikan pula proses pemaknaan mereka terhadap kepemimpinan organisasi dan apa implikasi terhadap langkah mereka dalam memimpin untuk meningkatkan kinerja organisasi. Berkaitan dengan hal di atas, maka akan dijelaskan wujud-wujud tindakan riil yang mereka hasilkan, dalam rangka memimpin organisasi.

\section{Konsep dan Tipologi Kepemimpinan}

Secara etimologi kepemimpinan berarti kemampuan dan kepribadian seseorang dalam mempengaruhi serta membujuk pihak lain agar melakuakan tindakan pencapaian tujuan bersama, sehingga dengan demikian yang bersangkutan menjadi awal struktur dan pusat proses kelompok. ${ }^{11}$

\footnotetext{
9 Intitusi Tekhnik Surabaya (2010), Jurnal Implementasi sistem pengukuran kinerja organisasi dengan metode integrated perfomance measurement syistem pada yayasan dana sosial al-falah, http://www.gooogle.co.id/url (accesed 01 april 2012) 1993), h. 51

10 Kartini Kartono, Pemimpin dan Kepemimpinan, (Jakarta: PT. Raja Grafindo Persada,

11 Inu Kencana, Kepemimpinan Pemerintahan Indonesia, (Bandung: Refika Aditama, 2003), h. 34
} 
Jadi kepemimpinan adalah aktivitas untuk mempengaruhi perilaku orang lain agar mereka mau diarahkan untuk mencapai tujuan tertentu. ${ }^{12}$ Kepemimpinan diartikan sebagai kemampuan menggerakkan atau memotivasi sejumlah orang agar secara serentak melakukan kegiatan yang sama dan terarah pada pencapaian tujuann. ${ }^{13}$

Oleh sebab itu, hal yang penting dari kepemimpinan adalah adanya pengaruh dan efektifnya kekuasaan dari seorang pemimpin. Jika seseorang berkeinginan mempengaruhi perilaku orang lain, maka aktivitas kepemimpinan telah mulai tampak relevansinya.

Seiring dengan pengertian di atas, pemimpin adalah orang yang mempunyai wewenang dan hak untuk memepengaruhi orang lain, sehingga mereka berprilaku sebagaimana yang dikehendaki oleh pemimpin tersebut melalui kepemimpinannya. Dengan demikian, secara sederhana kepemimpinan adalah setiap usaha untuk mempengaruhi. Sementara itu kekuasaan dapat diartikan sebagai suatu potensi pengaruh dari seorang pemimpin tersebut. Ini merupakan suatu sumber yang memungkinkan seorang pemimpin mendapatkan hak untuk mengajak atau mempengaruhi orang lain. ${ }^{14}$ Lebih lanjut, Miftah Toha juga membedakan antara kekuasaan dan otoritas (authority) yang sering dianggap sama pengertiannya. Authority dapat dirumuskan sebagai suatu tipe khusus dari kekuasaan yang secara asli melekat pada jabatan yang diduduki seseorang pemimpin. Dengan demikian otoritas adalah kekuasaan yang disahkan (legitimazed) oleh suatu peranan formal seorang pemimpin dalam sebuah organisasi. ${ }^{15}$

Berdasarkan uraian di atas, kepemimpinan perempuan adalah termasuk tipe kepemimpinan demokratik, karena jabatan yang disandangnya dari hasil pilihan organisasi, kendati pun banyak kalangan politikus dari partai-partai yang berasaskan Islam atau sebagian Ulama` menolaknya.

Pemimipin demokratik biasanya memandang peranannya selaku koordinator dari berbagai unsur dan komponen organisasi sehingga bergerak sebagai suatu totalitas, karena tipe pemimpin demokratik adalah tipe pemimipin yang paling ideal dan paling didambakan. Memang, harus diakui bahwa pemimpin yang demokratik tidak selalu merupakan pemimpin yang paling efektif dalam kehidupan organisasi sosial karena ada kalanya, dalam hal bertindak dan mengambil keputusan, bisa terjadi keterlambaatan sebagai konsekuensi keterlibatan para bawahan dalam proses pengambilan keputusan tersebut. Sekalipun demikian, pemimpin yang demokratik tetap dipandang sebagai pemimpin terbaik karena kelemahannya mengalahkan kekurangannya. ${ }^{16}$

Setiap organisasi membutuhkan para pemimpin yang dapat mengarahkan dan mengkoordinasikan kegiatan bersama dan aktivitas untuk kepentingan organisasi. Dan dengan cara yang dapat diterima, para pemimpin dapat merumuskan masalah dan mengusahakan pemecahannya. Jadi, seseorang menjadi pemimpin karena memang ada kebutuhan organisasi akan seorang yang

12 Miftah Toha, Kepemimpinan dalam Manajemen, (Jakarta : PT. Raja Grafindo Persada, 2007), h.

7

13 Nawawi dan M. Martin, Tekhnik Kepemimpinan Efektif, (Jakarta: PT. Raja Grafindo Persada, 2007), h. 1

${ }^{14}$ Miftah Toha, op.cit., h. 10

15 Ibid., h. 12

16 Sondang P. Siagian, , Teori dan Praktek Kepemimpinan, (Jakarta: Rhineka Cipta, 2003), h. 29 
dipilih, yang dianggap mampu mengadakan aktualisasi dan merealisasi dari kebutuhan yang dianggap sebagai keinginan organisasi.

Dari cara seorang pemimpin dalam melakukan kepemimpinannya itu dapat digolongkan atas beberapa tipologi:

a. Tipe Otokratis

Kepemimpinan secara otokratis adalah kepemimpinan yang cara memimpinnya menganggap organisasi sebagai miliknya sendiri. Sehingga seorang pemimpin bertindak sebagai diktator terhadap para anggota organisasinya dan menganggap mereka itu sebagai bawahannya dan merupakan alat atau mesin, tidak diperlakukan sebagaimana manusia. Bawahan hanya menurut dan menjalankan perintah atasannya serta tidak boleh membantah, karena pimpinan tidak mau menerima kritik, saran dan masukan.

Tipe kepemimpinan otokratis ini dapat kita jumpai dalam pemerintahan feodal oleh kerajaan-kerajaan pada zaman abad pertengahan. Kepemimpinan yang otokratis biasanya dikendalikan oleh seorang pemimpin yang mempunyai perasaan harga diri yang sangat tinggi. Bawahannya dianggap bodoh, tidak berpengalaman, dan selayaknya diperintah sesuka mereka.

Dengan egoisme yang sangat tinggi, seorang pemimpin yang otokratik melihat peranannya sebagai sumber segala sesuatu dalam kehidupan organisasional seperti kekuasaan yang tidak perlu dibagi dengan orang lain dalam organisasi, ketergantungan total para anggota organisasi mengenai nasib masing-masing dan sebagainya.

b. Tipe Paternalistik

Cara ini dapat dikatakan untuk seorang pemimpin yang bersifat kebapaan, ia menganggap bawahannya bagaikan anak yang belum dewasa. Tipe pemimpin yang paternalistik banyak terdapat di lingkungan masyarakat yang masih bersifat tradisional, umumnya di masyarakat agraris. Dengan demikian pemimpin semacam ini jarang sekali atau tidak pernah memberikan kepada bawahannya untuk bertindak sendiri, untuk mengambil inisiatif dan mengambil keputusan. Para bawahannya tidak diberi kesempatan untuk mengembangkan daya kreasi dan inovasinya. Konsekuensi dari perilaku demikian ialah bahwa para bawahannya tidak dimanfaatkan sebagai sumber informasi, ide, dan saran. Seorang pemimpin yang paternalistik ini dalam hal-hal yang tertentu sangat dibutuhkan, akan tetapi sebagai pemimpin pada umumnya kurang efektif.

c. Tipe Kharismatik

Rupanya sulit untuk menemukan sebab seorang pemimpin mempunyai kharisma. Yang jelas adalah bahwa pemimpin tersebut mempunyai daya tarik sendiri. Pemimpin yang kharismatik mampu menguasai bawahannya karena mereka diliputi oleh kepercayaan yang luar biasa terhadapnya. Para pengikut seorang pemimpin yang kharismatik tidak pernah mempersoalkan nilai yang diikuti, sikap, gaya dan perilaku yang digunakan pemimpin diikutinya. Keputusan dan kesetiaan para bawahannya timbul dari kepercayaan yang penuh kepada pemimpin yang dicintai, dihormati, dan dikagumi, bukan karena benar 
tidaknya alasan-alasan dan tindakan seorang pemimpin.

Kemampuan untuk menguasai bawahannya yang terdapat pada diri seorang pemimpin yang demokratis disebabkan kepercayaannya yang luar biasa kepada kemampuannya itu. Seorang pemimpin yang kharismatik adalah pemimpin yang dianggap mempunyai kekuatan ghaib atau kesaktian yang tidak dapat diindra secara ilmiah, sehingga dikagumi para bawahannya meskipun para bawahannya tidak selalu dapat menjelaskan secara konkrit mengapa orang tersebut dikagumi.

d. Tipe Laissez Faire

Dapat dikatakan bahwa persepsi seorang pemimpin yang laissez faire tentang peranannya sebagai seorang pemimpin berkisar pada pandangannya bahwa pada umumnya organisasi akan berjalan lancar dengan sendirinya karena para bawahannya terdiri dari orang-orang yang sudah dewasa yang mengetahui apa yang menjadi tujuan organisasi, sasaran apa yang ingin dicapai, tugas apa yang harus ditunaikan oleh masing-masing anggota dan seorang pemimpin tidak perlu terlalu sering melakukan intervensi dalam kehidupan organisasional.

Seorang pemimpin yang laissez faire melihat peranannya bagaikan polisi lalu lintas. Dengan anggapan bahwa para bawahannya sudah mengetahui dan cukup dewasa untuk taat kepada peraturan permainan yang berlaku, dan cenderung memiliki peranan yang pasif dan membiarkan bawahannya berjalan menurut tempatnya sendiri tanpa banyak mencampuri bagaimana bawahannya harus berjalan dan bergerak. Kepemimpinan semacam ini biasanya tidak kelihatan adan sebuah organisasi dan segalanya dilakukan tanpa ada rencana dari pemimpin.

Nilai-nilai yang dianut oleh seorang pemimpin yang laissez faire dalam menyelenggarakan fungsi-fungsi kepemimpinannya biasanya bertolak dari falsafah hidup bahwa manusia pada dasarnya memiliki rasa solidaritas dalam kehidupan bersama, mempunyai kesetiaan kepada sesama dan kepada organisasi, taat kepada norma-norma dan peraturan yang telah disepakati bersama, mempunyai tangguing jawab yang besar terhadap tugas yang harus diembannya. Dengan sikap demikian, maka tidak ada alasan kuat untuk memperlakukan para bawahannya sebagai orang-orang yang tidak dewasa, tidak bertanggung jawab, tidak setia dan tidak loyal. Nilai yang didasarkan dalam kepemimpinan tersebut adalah nilai saling mempercayai yang besar.

e. Tipe Demokratik

Seorang pemimpin yang demokratik dihormati dan segani dan bukan ditakuti karena perilakunya dalam kehidupan organisasional. Perilakunya memberi motivasi para bawahan nya menumbuhkan dan mengembangkan daya inovasi dan kreativitas nya. Dalam pelaksanaan tugas kepemimpinannya mau menerima saran-saran dari bawahannya dan bahkan kritik dimintanya dari mereka demi kesuksesan kinerja bersama. Ia memberi kebebasan yang cukup kepada bawahannya, karena menaruh kepercayaan yang besar bahwa mereka itu akan berusaha sendiri menyelesaikan tugasnya dengan baik. Untuk dapat mencapai hasil 
yang baik, seorang pemimpin yang demokratik senantiasa berusaha memupuk kekeluargaan dan persatuan, membangun semangat bekerja pada bawahannya. Satu lagi karakteristik penting yang dimiliki seorang pemimpin demokratik yang sangat positif adalah dengan cepat ia menunjukkan penghargaan kepada para bawahannya yang berprestasi baik. Penghargaan itu dapat berbentuk kata pujian, tepukan pada bahunya, memberikan piagam penghargaan, kenaikan pangkat atau bahkan mempromosikan jika keadaan memungkinkan. Seorang pemimpin yang demokratis akan bangga apabila para bawahannya menunjukkan kemampuan kerja yang bahkan lebih tinggi dari kemampuan dirinya sendiri.

Ciri-ciri gaya kepemimpinan demokratis

1. Semua kebijaksanaan terjadi pada kelompok diskusi dan keputusan diambil dengan dorongan dan bantuan dari pemimpin.

2. Kegiatan-kegiatan didiskusikan, langkah-langkah umum untuk tujuan kelompok dibuat, dan jika dibutuhkan petunjukpetunjuk teknis pemimpin menyarankan dua atau lebih alternatif prosedur yang dapat dipilih.

3. Para anggota bebas bekerja dengan siapa saja yang mereka pilih dan pembagian tugas ditentukan oleh kelompok.

Lebih lanjut ciri-ciri gaya kepemimpinan demokratis :

1. Lebih memperhatikan bawahan untuk mencapai tujuan organisasi.

2. Menekankan dua hal yaitu bawahan dan tugas.

3. Pemimpin adalah obyektif atau fact-minded dalam pujian dan kecamannya dan mencoba menjadi seorang anggota kelompok biasa dalam jiwa dan semangat tanpa melakukan banyak pekerjaan. ${ }^{17}$

\section{Kepemimpinan Perempuan dalam Perspektif Islam}

Pada zaman sekarang pemimpin dengan tipe demokratis inilah yang diharapkan dan dituntut masyarakat banyak, oleh karena kepemimpinan yang demokratik segala aktivitas dapat dikerjakan dengan baik sesuai dengan tujuan yang dicita-citakan. Seiring dengan konsep di atas, berikut akan dijelaskan rujukan para kaum perempuan tentang konsep kepemimpinan yang dijadikan landasan untuk bertindak. Yang pertama, dapat dipahami dari surat Fathir, ayat 39, yaitu:<smiles>CC[As]CCCCCC[As]C#[Si]</smiles>
bumi".18

Artinya : "Dialah Yang menjadikan kamu semua pemimpin (khalifah) di muka

Ayat ini merupakan penjelasan pernyataan Allah, bahwa Dia memposisikan manusia sebagai pemimpin (khalifah), tanpa memandang jenis kelaminnya baik perempuan maupun laki-laki. Dan dapat dipahami pula dari surat Ali-Imran ayat 195, sebagaimana disebutkan:

17 Ibid., h. 27-32

18 Departemen Agama RI, Al-Qur'an dan Terjemahannya, (Bandung: CV. Diponegoro, 2000) h. 


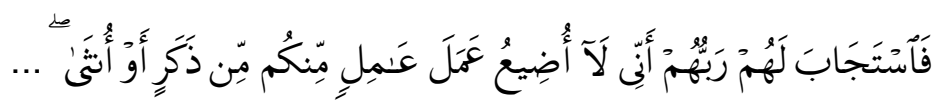

Artinya : "Maka Tuhan mereka memperkenankan permohonannya (dengan berfirman): "Sesungguhnya aku tidak menyia-nyiakan amal orang-orang yang beramal di antara kamu, baik laki-laki atau perempuan" (Ali Imran: 195)19

Dan juga dalam surat At Taubah ayat 71 dikatakan:

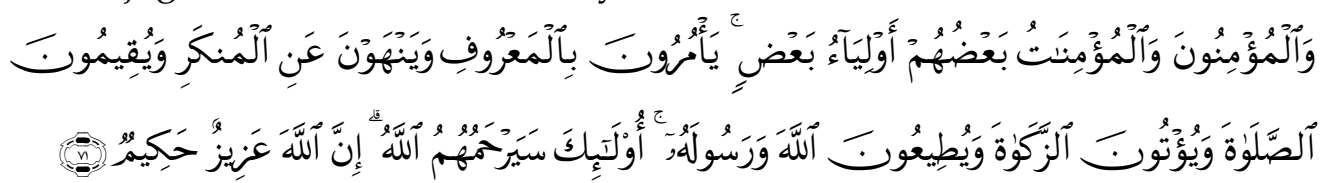

Artinya : "Dan orang-orang yang beriman, lelaki dan perempuan, sebahagian mereka (adalah) menjadi penolong bagi sebahagian yang lain. mereka menyuruh (mengerjakan) yang ma'ruf, mencegah dari yang munkar, mendirikan shalat, menunaikan zakat dan mereka taat pada Allah dan Rasul-Nya. mereka itu akan diberi rahmat oleh Allah; Sesungguhnya Allah Maha Perkasa lagi Maha Bijaksana." (At Taubah: 71)20

Ayat di atas secara jelas berusaha untuk mengkikis habis berbedaan jenis kelamin (gender), khususnya dalam arti kemanusiaan. Secara umum kaum laki-laki dan perempuan mempunyai hak yang sama dalam setiap aspek kehidupan. Disisi lain, pada masa Nabi Sulaiman, di negeri yang diabadikan sebagai salah satu nama surat dalam Al-Qur`an yang dikenal "baldatun thayyibatun wa rabbun ghafur" (negeri yang adil, makmur, aman, dan sentosa), yaitu negeri Saba`. Negeri ini ternyata dipimpin oleh penguasa perempuan, Ratu Bilqis.

Sedangkan pada awal perkemba ngan Islam pun, Ummul Mu`minin Siti 'Aisyah juga pernah menjadi seorang panglima perang dalam perang jamal. Realita semacam ini akan menjadi tendensi dan semakin melunturkan larangan perempuan untuk tampil sebagai serang pemimipin publik. ${ }^{21}$

Disamping itu Al-Qur'an secara tegas memberikan pandangan tentang kesetaraan laki-laki dan perempuan dilihat dari ayat yang membicarakan Adam dan Hawa, sampai mereka terlempar ke bumi, selalu menggunakan bentuk kata ganti mereka berdua (huma).

\section{Kepemimpinan Perempuan dalam Organisasi}

Pada dasarnya manusia merupakan makhluk sosial, karena manusia dalam kehidupannya tidak dapat berdiri sendiri dan sangat membutuhkan orang lain. Kebutuhan tersebut diantaranya ialah kebutuhan akan saling interaksi antar individu sehingga satu sama lain dapat dimengerti. Dengan kata lain, manusia memiliki kepentingan untuk berorganisasi sebagai upaya mewujudkan kebutuhan bersama yang telah ditentukan.

Suatu fitrah bagi manusia untuk memiliki keinginan dalam mencapai kekuasaan dan pengaruh, sehingga manusia dikategorikan sebagai makhluk politik. Kepentingan tersebut pada umumnya tercermin dari keinginan untuk turut serta dilibatkan dalam berorganisasi, baik sebagai seorang pemimpin maupun yang dipimpin. Sekalipun ada kalangan seseorang yang tidak serta merta mampu mengekspresikan visi organisasinya. Akan tetapi kemampuan demikian dapat ditumbuhkan dan dikembangkan.

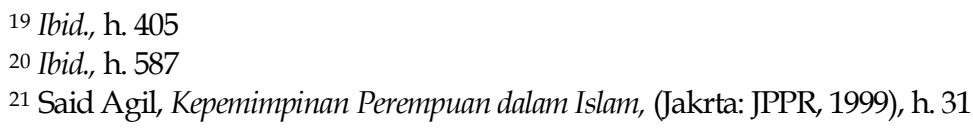


Organisasi merupakan gabungan sejumlah orang yang saling bekerjasama untuk mencapai tujuan bersama. Keterlibatan seseorang dalam organisasi baik yang berbentuk organisasi formal maupun informal, didasari keinginan untuk memperoleh sesuatu seperti: keinginan untuk menambah pengetahuan, mengembangkan diri, atau sekedar memperluas jaringan pertemanan belaka. Jika kita mengamati, banyak sekali muncul organisasi di semua kalangan. Apakah dikalangan professional, buruh, ibu rumah tangga, remaja, mahasiswa dan lain sebagainya. Anggota dalam organisasi tersebut umumnya terdiri dari berbagai strata pendidikan, ekonomi, umur, suku/budaya, agama maupun jenis kelamin, baik laki-laki maupun perempuan, keduanya sama-sama punya peluang besar untuk menempati kedudukan penting dalam organisasi. Melihat kecenderungan yang tampak saat ini, khusunya pada organisasi kemahasiswaan, perempuan telah menempat beberapa posisi-posisi penting dalam organisasi.

Terlebih lagi, banyak terdapat organisasi keperempuanan, baik dalam bentuk ormas, LSM, maupun organisasi pengkaderan. Dengan kata lain, perempuan memiliki tempat tersendiri dalam melakukan perubahan dalam dirinya dan masyarakat, melalui pemahaman dan penerapan nilai-nilai kepemimpinan.

Dalam suatu organisasi, kepemimpinan merupakan salah satu faktor penentu bagi kemajuan organisasi. Pemimpin yang berada pada organisasi formal akan memiliki kekuasaan manajemen yang didasarkan pada prinsip-prinsip manajemen pula. Sehingga pemimpin yang dimilikinya bersifat institusional dan tidak dihubungkan dengan sifat-sifat pribadi. Dengan demikian bahwa seorang pemimpin dapat meningkatkan hasil yang lebih baik dari sebelumnya dan memiliki prestasi kerja yang lebih baik pula. Sehingga seorang pemimpin perempuan akan diakui kepemimpinannya oleh bawahannya maupun orang lain karena kemampuan yang lebih baik apalagi berhasil mencapai tujuan organisasi yang dipimpinnya.

Perempuan yang mampu dan bertindak sebagai pemimpin, dalam arti mampu mengambil keputusan yang tepat. Hal ini merupakan sifat yang diperlukan seorang pemimpin, tanpa hal yang itu sangat sulit dilakukan, mengingat banyak pendapat bahwa wanita adalah makhluk yang lemah, tetapi sebenarnya tidaklah demikian.

Perempuan sebagai pemimpin tidak jarang menghadapi banyak hambatan. Untuk lebih jelasnya Ibrahim sebagaimana dikutip oleh Tan menguraikan beberapa hambatan yang muncul dalam kepemimpinan perempuan sebagai berikut :

1. Hambatan Fisik

Perempuan, katanya, dibebani tugas "kontrak", untuk mengandung, melahirkan, dan menyusui. Keharusan ini mengurangi keleluasaan mereka untuk aktif terus-menerus dalam berbagai bidang kehidupan. Bayangkan jika perempuan harus melahirkan lebih dari selusin anak. Pastilah usia produktifnya habis dipakai untuk tugas-tugas reproduktif yang mulia itu.

2. Hambatan Teologis

Untuk waktu yang lama perempuan dipandang sebagai makhluk yang dicipta untuk lelaki. Termasuk mendampingi mereka, menghiburnya, dan mengurus keperluannya. Perempuan, menurut cerita teologis seperti ini, diciptakan dari rusuk laki-laki. Cerita ini telah jauh merasuk dalam benak banyak orang, dan secara psikologis merupakan faktor penghambat perempuan untuk mengambil peran yang berarti. 
3. Hambatan Sosial Budaya

Terutama dalam bentuk stereotipikal. Pandangan ini melihat perempuan sebagai makhluk yang pasif, lemah, perasa, tergantung, dan menerima keadaan. Sebaliknya laki-laki dipandang makhluk yang kuat, aktif, cerdas, mandiri, dan sebagainya. Pandangan ini menempatkan laki-laki secara sosiokultural lebih tinggi "derajatnya" dibanding perempuan.

4. Hambatan Sikap Pandang

Hambatan ini antara lain bisa dimunculkan oleh pandangan dikotomistis antara tugas perempuan dan laki-laki. Perempuan dipandang sebagai makhluk rumah, sedangkan laki-laki dipandang sebagai makhluk luar rumah. Pandangan dikotomistis seperti ini bisa jadi telah membuat perempuan risih keluar rumah, dan visi bahwa tugas-tugas kerumahtanggaan tidak layak digeluti laki-laki.

5. Hambatan Historis.

Kurangnya nama perempuan dalam sejarah dimasa lalu bisa dipakai membenarkan ketidakmampuan perempuan untuk berkiprah seperti halnya laki-laki.22

Kelima hambatan terebut menyebabkan potensi kepemimpinan perempuan menjadi tidak mendapat tempat yang layak didalam kehidupan tetapi dengan adanya arus informasi dan komunikasi yang masuk dan diterima oleh kaum perempuan menyebabkan kesempatan untuk mengembangkan diri dan kepemimpinannya menjadi terbuka lebar.

Untuk dapat menjadi seorang pemimpin bagi perempuan tidaklah mudah, terutama sekali adalah kemampuan yang ada dalam dirinya ditunjang oleh latar belakang pendidikannya yang sesuai dengan bidang yang akan dipegangnya, sehingga untuk menjadi seorang pemimpin yang berhasi terdapat beberapa nilai dasar kepemimpinan, menurut Tilaar (dalam Tan), sebagai berikut:

a. Intelegensi yang relatif lebih tinggi daripada yang dipimpin;

b. Berfikir positif;

c. Kedewasaan sosial dan cakupan jangkauan yang luas;

d. Menjadi panutan yang baik;

e. Menjadi pendengar yang baik;

f. Keterbukaan dalam berkomunikasi;

g. Tidak mudah menyerah. ${ }^{23}$

Nilai dasar kepemimpinan tersebut merupakan arah yang harus dijalankan seorang pemimpin dalam menjalankan organisasi yang dipimpinnya sesuai dengan tujuan yang harus dicapai. Dengan demikian kepemimpinan antara perempuan dan laki-laki tidak ada lagi bedanya, apabila telah menjalankan nilai dasar kepemimpinan tersebut.

\section{Kinerja Organisasi}

Kinerja adalah hasil kerja yang dapat dicapai seseorang atau sekelompok orang dalam suatu organisasi sesuai dengan wewenang dan tanggung jawab masing-

22 Melly G. Tan, Perempuan Indonesia Pemimpin Masa Depan?, (Jakarta : Pustaka Sinar Harapan, 1991), h. 16

${ }^{23}$ Ibid., h. 71-72 
masing dalam rangka mencapai tujuan organisasi dalam periode waktu tertentu. ${ }^{24}$ Kinerja juga diterjemahkan sebagai suatu gambaran mengenai tingkat pencapaian pelaksanaan suatu kegiatan/program/kebijakan dalam mewujudkan sasaran, tujuan, misi dan visi organisasi yang tertuang dalam strategic planning suatu organisasi. ${ }^{25}$ Dengan demikian berdasarkan kedua definisi tersebut penulis dapat simpulkan bahwa memberi penegasan kinerja pada dasarnya merupakan hasil yang telah dicapai khususnya dalam hal pencapaian program yang telah direncanakan sebelumnya. Dan juga kinerja organisasi berhubungan erat dengan kepemimpinannya, apabila kepemimpinannya baik maka kemungkinan besar kinerja organisasinya juga baik.

\section{Efektivitas dan Optimalisasi Kinerja Organisasi}

Efektivitas kinerja ialah pencapaian tujuan atau hasil yang dikehendaki tanpa menghiraukan faktor-faktor tenaga, waktu, biaya, fikiran, alat-alat dan lain-lain yang telah dikeluarkan atau digunakan. ${ }^{26}$ Dalam arti bahwa segala sesuatu yang dikerjakan dengan berdaya guna dan berhasil guna artinya dengan tepat, cepat, hemat. Dengan demikian dapat diidentifikasikan faktor yang berpengaruh langsung terhadap tingkat pencapaian kinerja organisasi sebagai berikut:

1. Teknologi yang meliputi peralatan kerja dan metode kerja yang digunakan untuk mengahasilkan produk atau jasa yang dihasilkan oleh organisasi. Semakin berkualitas teknologi yang digunakan, maka akan semakin tinggi tingkat kinerja organisasi tersebut.

2. Kualitas input atau material yang digunakan oleh organisasi.

3. Kualitas lingkungan fisik yang meliputi keselamatan kerja, penataan ruangan, dan kebersihan.

4. Budaya organisasi sebagai pola tingkah laku dan pola kerja yang ada dalam organisasi yang bersangkutan.

5. Kepemimpinan sebagai upaya untuk mengendalikan anggota organisasi agar bekerja sesuai dengan standar dan tujuan organisasi.

6. Pengelolaan sumber daya manusia yang meliputi aspek kompensasi, imbalan, dan promosi. ${ }^{27}$

Berhasil tidaknya tujuan dan cita-cita dalam organisasi tergantung bagaimana proses kinerja itu dilaksanakan. Kinerja tidak lepas dari faktor-faktor yang mempengaruhi. Berikut faktor-faktor yang mempengaruhi kinerja:

1. Faktor Kemampuan (Ability)

Secara psikologis, kemampuan ability terdiri dari kemampuan potensi IQ dan kemampuan reality, knowledge, dan skill. Artinya pimpinan dan karyawan yang memiliki IQ superior, very superior, gifted dan genius dengan pendidikan yang memadai untuk jabatan dan terampil dalam menjalankan pekerjaan sehari-hari maka akan mudah menjalankan kinerja maksimal.

2. Faktor Motivasi (Motivation)

Motivasi diartikan sebagai suatu sikap attitude pimpinan dan karyawan terhadap situasi kerja situation dilingkungan organisasinya. Mereka yang

24 Suyadi Prawirosentono, Analisis Kinerja Organisasi, (Jakarta: PT. Rineka Cipta, 1999), h. 4

25 Mohamad Mahsud, Pengukuran Kinerja Sektor Publik, (Yogyakarta: BPFE, 2009), h.

26 Ibid., h. 27

27 Paul L. Tobing, Ilmu Manajemen: Konsep dan Implementasi, (Jakarta: Graha Ilmu, 2007), h. 69 
bersikap positif pro terhadap situasi kerjanya akan menunjukan motivasi kerja tinggi dan sebaliknya jika mereka berpikir negatif kontra terhadap situasi kerjanya akan menunjukan pada motivasi kerja yang rendah. Situasi yang dimaksud meliputi hubungan kerja, fasilitas kerja, iklim kerja, kebijakan pimpinan, pola kepemimpinan kerja dan kondisi kerja.

Motivasi diartikan juga sebagai suatu kekuatan sumber daya yang menggerakkan dan mengendalikan perilaku manusia. Motivasi sebagai upaya yang dapat memberikan dorongan kepada seseorang untuk mengambil suatu tindakan yang dikehendaki, sedangkan motif sebagai daya gerak seseorang untuk berbuat. Karena perilaku seseorang cenderung berorientasi pada tujuan dan didorong oleh keinginan untuk mencapai tujuan tertentu.

Dalam konteks pekerjaan, motivasi merupakan salah satu faktor penting dalam mendorong seorang karyawan untuk bekerja. Motivasi adalah kesediaan individu untuk mengeluarkan upaya yang tinggi untuk mencapai tujuan organisasi. Ada tiga elemen kunci dalam motivasi yaitu upaya, tujuan organisasi dan kebutuhan. Upaya merupakan ukuran intensitas. Bila seseorang termotivasi maka ia akan berupaya sekuat tenaga untuk mencapai tujuan, namun belum tentu upaya yang tinggi akan menghasilkan kinerja yang tinggi. Oleh karena itu, diperlukan intensitas dan kualitas dari upaya tersebut serta difokuskan pada tujuan organisasi. Kebutuhan adalah kondisi internal yang menimbulkan dorongan, dimana kebutuhan yang tidak terpuaskan akan menimbulkan tegangan yang merangsang dorongan dari dalam diri individu. Dorongan ini menimbulkan perilaku pencarian untuk menemukan tujuan, tertentu. Apabila ternyata terjadi pemenuhan kebutuhan, maka akan terjadi pengurangan tegangan. Pada dasarnya, karyawan yang termotivasi berada dalam kondisi tegang dan berupaya mengurangi ketegangan dengan mengeluarkan upaya.

Ciri-ciri yang memiliki motivasi berprestasi yang tinggi menurut Mc Clelland adalah:

1. Menyukai tanggungjawab untuk memecahkan masalah.

2. Cenderung menetapkan target yang sulit dan berani mengambil risiko

3. Memiliki tujuan yang jelas dan realistik.

4. Memiliki rencana kerja yang menyeluruh

5. Lebih mementingkan umpan balik yang nyata tentang hasil prestasinya.

6. Senang dengan tugas yang dilakukan dan selalu ingin menyelesaikan dengan sempurna.

Berdasarkan pengertian diatas bahwa suatu kinerja dipengaruhi oleh beberapa faktor pendukung dan penghambat berjalannya suatu pencapaian kinerja yang maksimal faktor tersebut meliputi faktor yang berasal dari intern maunpun ekstern. Menilai suatu kinerja apakah sudah berjalan dengan yang direncanakan perlu diadakan suatu evaluasi kinerja. 


\section{Kepemimpinan Perempuan dalam Peningkatan Kinerja Organisasi}

Peranan kepemimpinan perempuan dalam organisasi dapat diartikan sebagai serangkaian prilaku yang dilakukan oleh perempuan sesuai dengan kedudukannya sebagai pemimpin dalam organisasi. Apabila perempuan telah masuk dan terlibat dalam sektor publik khususnya memegang peranan sebagai pemimpin dalam organisasi, ada beberapa hal fundamental yang mempengaruhi posisinya, antara lain:

1. Nilai-nilai Sosial

Nilai sosial dimaksudkan sebagai pengendali perilaku manusia. Nilai sosial ini merupakan ukuran-ukuran di dalam menilai indakan dalam hubungannya dengan orang lain. Nilai-nilai sosial ini orang yang satu dapat memperhitungkan apa yang dilakukan oleh orang lain. Sementara Soejono Soekanto mendefenisikan sebagai konsepsi abstrak di dalam diri manusia mengenai apa yang dianggap baik dan apa yang dianggap buruk ${ }^{28}$. Dari definisi di atas terlihat bahwa nilai-nilai sosial ini menjadi patokan atau ukuran dari masyarakat yang bersangkutan, yang bertujuan untuk mengadakan tata atau ketertiban.

Nilai-nilai yang ada dalam suatu masyarakat bersifat dinamis. Ia akan selalu mengalami perubahan, bersamaan dengan meningkatnya pengalaman, baik yang diperoleh dari luar masyarakatnya atau perkembangan pola pikir yang selaras dengan tuntutan jaman. Hal ini akan berakhir pada berubahnya nilai-nilai sosial yang dianut. Namun begitu ada nilai-nilai tertentu yang relatif sulit mengalami perubahan, misalnya agama.

Terjadinya perubahan tersebut, baik disengaja atau tidak, akan berpengaruh terhadap peran-peran yang harus dijalankan dalam institusi yang bersangkutan. Keluarga merupakan institusi terkecil dari masyarakat juga mengalami hal demikian. Beberapa peran tersebut ada yang kita warisi, ada yang kita ciptakan dan ada pula yang muncul bersamaan dengan aktifitas kita ${ }^{29}$. Oleh karena itu peran-peran tersebut ditentukan oleh keluarga dan lingkungan budaya kita. Pertentangan timbul jika ketentuan peran dan perasaan kita sendiri tidak sama, sehingga mulai timbul konflik dalam menjalankan peran tersebut. Hal ini disebabkan tidak semua perubahan terjadi dengan mudah, masih dibutuhkan penyesuaianpenyesuaian yang seringkali menimbulkan konflik. Hal yang sama terjadi jika wanita memasuki sektor publik secara lebih khusus bila ia menempati posisi sebagai pemimpin dalam organisasi, ia dinilai mendobrak kemampuan atas sistem nilai yang telah mengakar kuat.

2. Status Sosial

Setiap individu dalam masyarakat memiliki status sosialnya masingmasing. Status merupakan perwujudan atau pencerminan dari hak dan kewajiban individu dalam tingkah lakunya. Status sosial sering pula disebut sebagai kedudukan atau posisi, peringkat seseorang dalam kelompok masyarakatnya. Pada semua sistem sosial, tentu terdapat berbagai macam kedudukan atau status, seperti anak, isteri, suami dan sebagainya. Cara-cara individu memperoleh status atau kedudukan adalah sebagai berikut:

28 Soedjito Sosrodiharjo, Norrma-norma Sosial, (Jakarta: Repelita, 2008), Cet. Ke-5, h. 65.

29 Abdurrahman, Nilai-nilai Indonesia dan Transformasi Kebudayaan, (Jakarta: Cypress, 2008), Cet. Ke-3, h. 132. 
a. Ascribed Status adalah kedudukan yang diperoleh secara otomatis tanpa usaha seperti : Jenis kelamin, gelar kebangsawanan, keturunan, dan sebagainya.

b. Achieved Status adalah kedudukan yang diperoleh seseorang dengan disengaja, misalnya yang diperoleh melalui pendidikan dokter.

c. Assigned Status merupakan kombinasi dari perolehan status secara otomatis dan status melalui usaha. Status ini diperoleh melalui penghargaan atau pemberian dari pihak lain, atas jasa perjuangan sesuatu untuk kepentingan atau kebutuhan masyarakat.

Kadangkala seseorang/individu dalam masyarakat memiliki dua atau lebih status yang disandangnya secara bersamaan. Apabila status-status yang dimilikinya tersebut berlawanan akan terjadi benturan atau pertentangan. Hal itulah yang menyebabkan timbul apa yang dinamakan Konflik Status. Jadi akibat yang ditimbulkan dari status sosial seseorang adalah timbulnya konflik status. Konflik status dapat digolongkan menjadi tiga kelompok yaitu :

a. Konflik status bersifat individual, yaitu konflik status dirasakan seseorang dalam hatinya sendiri.

b. Konflik status antar individu terjadi antara individu yang satu dengan individu yang lain, karena status yang dimilikinya.

c. Konflik status antar kelompok karena kedudukan atau status yang terjadi antara kelompok yang satu dengan kelompok yang lain.

Memilih sebagai wanita karier atau ibu rumah tangga merupakan persoalan (konflik status) yang harus dihadapi seorang wanita apabila ia masuk kedalam sektor publik dan menempati posisi sebagai pemimpin dalam organisasi.

1. Komunikasi

Komunikasi sangatlah penting bagi organisasi, bahwa setiap organisasi yang tuntas, komunikasi akan mendukung suatu tempat utama, karena susunan, keluasan, dan cakupan organisasi secara keseluruhan ditentukan oleh teknik komunikasi ${ }^{30}$. Thoha juga mengatakan bahwa komunikasi sangat penting mengingat suatu program hanya dapat dilaksanakan dengan baik apabila program jelas bagi pelaksana, hal ini menyangkut penyampaian informasi, kejelasan dan informasi yang disampaikan dan konsistensi dari informasi tersebut. Komunikasi juga bertujuan untuk mengembangkan suatu iklim yang mengurangi tekanan dan konflik di dalam masyarakat, maka komunikasi tidak hanya harus datang dari atas, melainkan timbal balik.

Komunikasi organisasi didefinisikan sebagai komunikasi insani yang terjadi dalam konteks organisasi ${ }^{31}$. Disebut demikian karena manusialah yang berkomunikasi dalam organisasi tersebut atau antara manusia anggota organisasi yang satu dengan yang lainnya dan bukan organisasinya sendiri. Ciri-ciri utama dari komunikasi organisasi ini adalah faktor-faktor struktural yang ada dalam organisasi yang mengharuskan para anggotanya bertindak sesuai dengan peranan yang diharapkan.

Dalam organisasi, komunikasi memiliki empat fungsi. Pertama, menyediakan informasi yang sesuai dengan kebutuhan anggota organisasi

30 Miftah Thoha, Komunikasi Organisasi Strategi Meningkatkan Kinerja, (Jakarta: MPA,

\footnotetext{
31 Ibid, h. 97
} 
untuk membuat keputusan. Kedua, sebagai alat untuk memotivasi anggota. Komunikasi dibutuhkan untuk menjelaskan tujuan organisasi, memberikan umpan balik terhadap pencapaian tujuan dan penguatan terhadap perilaku anggota. Ketiga, sebagai alat untuk mengendalikan perilaku. Keempat, sebagai media untuk mengungkapkan emosi antara lain rasa kecewa, rasa puas an lain-lain.

Apabila kita mampu melaksanakan komunikasi dengan baik dan sarat dengan pesan-pesan yang komunikatif, akan diperoleh keuntungankeuntungan tertentu yaitu ${ }^{32}$ :

a. Kelancaran tugas-tugas lebih terjamin

b. Biaya-biaya dapat ditekan

b. Dapat meningkatkan partisipasi

c. Pengawasan dapat dilakukan dengan baik

Dari penjelasan di atas komunikasi merupakan faktor yang sangat penting dalam organisasi yang baik secara langsung maupun secara tidak langsung mempengaruhi posisi wanita sebagai pemimpin dalam jabatan publik. Jika seseorang dapat mencapai kekuasaan atas kemampuannya sendiri, hal ini disebabkan karena ia mampu membangun basis kekuasaan keorganisasian karena ditunjang oleh arus komunikasi yang efektif.

2. Pendidikan

Pendapatan (income), pendidikan dan status merupakan faktor penting dalam proses memperoleh jabatan atau dengan kata lain, orang yang berpendapatan tinggi, yang berpendidikan tinggi, dan berstatus sosial tinggi. Cenderung lebih banyak daripada orang yang berpendapatan serta pendidikan yang rendah. ${ }^{33}$

Peningkatan peranan wanita dalam dunia kerja ternyata ditunjang dengan peningkatan tingkat pendidikan wanita. Mereka yang berpendidikan cukup tinggi memiliki pengetahuan dan informasi lebih baik dibandingkan mereka yang berpendidikan lebih rendah atau tidak sekolah. Dengan model tersebut, mereka yang berpendidikan tinggi lebih memahami makna kehidupan politik sehingga lebih cenderung terlibat dalam kegiatan publik. Pekerjaan yang lebih baik yang dimiliki seseorang mencerminkan kemampuan orang tersebut, terutama dalam tingkat intelektual dan kemampuan pribadi lainnya.

Bagi wanita yang memilih bekerja setelah mengenyam pendidikan tinggi, kemungkinan besar akan mendapat dukungan dari sebagian masyarakat yang beranggapan bahwa sekolah atau pendidikan adalah untuk mencari pekerjaan. Pekerjaan dianggap sebagai pemberi status, seperti yang dikemukakan oleh seorang wanita sebagai berikut ${ }^{34}$ :

"Walau bermimpi menjadi ibu rumah tangga, saya ragu apakah orang masih memandang saya kalau berhenti bekerja karena pekerjaan memberi saya status,"

Sementara bagi wanita yang memilih mendidik anak, keluarga atau bekerja di sektor informal di luar kantor, kemungkinan besar akan mendapat tantangan dari kelompok masyarakat yang menganggap sekolah adalah untuk mencari pekerjaan. Namun akan mendapat

\footnotetext{
32 Ibid, h. 104

33 Soedjito Sosrodiharjo,Op-Cit, h 89.

34 Deborah, Editor, (Kosmopolitan: 2000), h. 67
} 
dukungan bagi mereka yang berpendapat bahwa ilmu adalah harta yang paling bernilai dan akan semakin bernilai jika diamalkan dalam ruang lingkup yang tak terbatas pada ruang kantor semata.

Ada kalanya seorang wanita benar-benar ingin menjadi ibu rumah tangga seratus persen dengan tujuan dapat lebih berkonsentrasi mengikuti perkembangan anak dengan bekal pendidikan yang dimiliki. Namun keinginan itu seringkali harus berhadapan dengan 'keinginan' masyarakat Indonesia secara umum, karena diaku atau tidak, ada perubahan nilai yang terjadi di masyarakat yaitu dari wanita sebagai pengurus rumah tangga yang tidak memerlukan pendidikan tinggi menjadi wanita yang harus sekolah untuk kelak juga bekerja di kantor dan terpanang. "Buat apa sekolah susahsusah kalau Cuma di rumah mengurus anak?!" Kurang lebih begitulah tanggapan yang akan didengar jika melihat seorang wanita berpendidikan tinggi yang memilih menjadi ibu rumah tangga. Perbedaan pandangan yang terjadi baik pada masyarakat luas maupun wanita berpendidikan itu sendiri tidak lepas dari latar belakang budaya yang ada.

3. Pengalaman Kerja

Ada dua sudut pandang yang berbeda yang menyebabkan para wanita memili untuk tetap bekerja meskipun sudah menikah. Pertama untuk meningkatkan standar ekonomi keluarga dalam arti karena adanya kebutuhan ekonomi, dan yang kedua untuk meningkatkan kualitas hidup seperti keinginan untuk memuaskan diri sendiri, ketertarikan dalam melakukan sesuatu, atau mengaktualisasikan kemampuan yang ada.

Uang bukanlah satu-satunya motif bagi wanita untuk bekerja, tapi lebih pada pemenuhan kebutuhan intelektual atau kebutuhan untuk berprestasi. Ada pula wanita yang sebenarnya tidak terlalu berambisi terhadap profesi atau pekerjaan tetapi tetap melanjutkan bekerja meskipun sudah menikah. Hal ini terjadi karena para wanita ini telah terbiasa bekerja dan tidak terbiasa untuk diam di rumah sebagai ibu rumah tangga biasa.

Pengalaman kerja menentukan kesuksesan seseorang dalam karir yang dipengaruhi oleh bentuk dan jenis tugas serta jenis pekerjaan yang spesifik, sehingga mendorong orang mencapai penyelesaian yang sempurna dan lebih baik dibandingkan orang lain, Penelitian dari Mc. Enery \& Ms. Enery menunjukkan bahwa keinginan untuk sukses dalam karir mendorong seseorang mencari jalan untuk berkembang melalui pelatihan-pelatihan serta lebih suka memilih tugas-tugas yang penuh tantangan.

Berdasarkan uraian di atas, ada beberapa kendala yang dihadapi oleh wanita yang menempati posisi sebagai pemimpin dalam organisasi. Kendala tersebut dapat dibedakan ke dalam tiga kelompok yaitu :

a. Kendala yang bersifat internal,

b. Kendala yang bersifat eksternal, dan

c. Kendala yang merupakan interaksi antara kedua hal tersebut.

\section{Simpulan}

Kepemimpinan perempuan dalam penigkatan kinerja organisasi pada KOPRI Wilayah Lampung, maka penulis dapat menyimpulkan. Tipe kepemimpinan yang digunakan oleh KOPRI Wilayah Lampung ialah tipe kepemimpinan demokratik, hal ini dapat diketahui bahwa setiap akan merencanakan maupun menetapkan 
keputusan atau kebijakan selalu mengedepankan musyawarah, serta tidak menutupkemungkinan argumentasi dari anggota menjadi keputusan yang disepakati oleh organisasi. Pelaksanaan kegiatan di KOPRI secara umum memberikan manfaat yang berarti bagi anggota walaupun tidak berjalan dengan baik. Anggota dapat meningkatkan kapabilitas mereka dengan adanya kegiatan keperempuanan. Saat ini kegiatan-kegiatan yang ada di KOPRI Lampung masih dalam tahap pengembangan. Masih terdapat inkonsistensi pelaksanaan yang tidak sesuai AD/ART dan lemahnya peranan dari Pengawas. Anggota yang seharusnya tidak berhak aktif tetap dapat aktif sehingga hak orang lain dikorbankan. Selain itu masih ada anggota kelompok yang menyalahgunakan dana kegiatan. Uang yang seharusnya digunakan untuk kegiatan, digunakan untuk memenuhi kebutuhan sehari-hari. Partisipasi anggota terutama perempuan dalam KOPRI masih tergolong rendah, hal ini terlihat karena tidak semua anggota yang ada di KOPRI turut serta di dalamnya. Pembagian tugas dalam bidang antara ketua, bendahara dan sekretaris tidak berjalan seimbang. Ketua memegang kendali penuh atas bidang sehingga kegiatan bidang tidak berjalan dengan baik. Dalam pelaksanaan kegiatan di KOPRI masih terdapat kasus gender, yakni adanya peran ganda dari anggota aktif yang selain mencari ilmu sebagai mahasiswa juga harus mengurus pekerjaan anggota lain yang tidak aktif, serta adanya pengaruh kekuasaan atau jabatan seseorang yang diterapkan dalam KOPRI. Seseorang yang menjabat sebagai sekretaris seakaligus sebagai bendahara dapat dengan mudah mengikutsertakan anggota lainnya yang merupakan teman dekatnya sebagai anggota dalam bidangnya. Kurangnya kesadaran anggota mengenai masalah gender juga terlihat dari pelaku-pelaku KOPRI yang ada di KOPRI Lampung. Masalah ekonomi dan SDM yang rendah menjadi penghambat utama KOPRI Lampung terutama perempuan untuk dapat turut serta dalan kegiatan KOPRI.

\section{Referensi}

Abdurrahman, Nilai-nilai Indonesia dan Transformasi Kebudayaan, (Jakarta: Cypress, 2008), Cet. Ke-3

Abu Yasid, Fikih Politik, (Jakarta: Erlangga, 2005)

Arief Subhan, dkk., Citra Perempuan Dalam Ialam: Pandangan Ormas keagamaan, (Jakarta: PT. Gramedia Pustaka Utam,a, 2003)

Deborah, Editor, (Kosmopolitan: 2000)

Departemen Agama RI, Al-Qur'an dan Terjemahannya, (Bandung: CV. Diponegoro, 2000)

Departemen Agama RI, Al-Qur'an dan Terjemahan, (Bandung: CV. Diponegoro, 2000)

Fitri Chindiathia, Ketua Umum KOPRI Wilayah Lampung, interview tanggal 02 April 2012

Intitusi Tekhnik Surabaya (2010), Jurnal Implementasi sistem pengukuran kinerja organisasi dengan metode integrated perfomance measurement syistem pada yayasan dana sosial al-falah, http:// www.gooogle.co.id/url (accesed 01 april 2012)

Inu Kencana, Kepemimpinan Pemerintahan Indonesia, (Bandung: Refika Aditama, 2003)

Irma Muthoharoh (2011), Artikel KOPRI-PB.PMII Kawah Canra dimuka kepemimpinan Perempuan PMII,www.kopri.pmii.or.id/ (Accesed 01 april 2012)

Kartini Kartono, Pemimpin dan Kepemimpinan, (Jakarta: PT. Raja Grafindo Persada, 1993) 
Melly G. Tan, Perempuan Indonesia Pemimpin Masa Depan?, (Jakarta : Pustaka Sinar Harapan, 1991)

Miftah Thoha, Komunikasi Organisasi Strategi Meningkatkan Kinerja, (Jakarta: MPA, 2007)

Miftah Toha, Kepemimpinan dalam Manajemen, (Jakarta : PT. Raja Grafindo Persada, 2007)

Mohamad Mahsud, Pengukuran Kinerja Sektor Publik, (Yogyakarta: BPFE, 2009) Muhyidin Mas Rida, Wanita dalam Fikih Qardhawi, (Jakarta: Pustaka Al-Kautsar, 2009)

Nawawi dan M. Martin, Tekhnik Kepemimpinan Efektif, (Jakarta: PT. Raja Grafindo Persada, 2007)

Paul L. Tobing, Ilmu Manajemen: Konsep dan Implementasi, (Jakarta: Graha Ilmu, 2007)

Said Agil, Kepemimpinan Perempuan dalam Islam, (Jakrta: JPPR, 1999)

Soedjito Sosrodiharjo, Norrma-norma Sosial, (Jakarta: Repelita, 2008), Cet. Ke-5

Sondang P. Siagian, , Teori dan Praktek Kepemimpinan, (Jakarta: Rhineka Cipta, 2003)

Suyadi Prawirosentono, Analisis Kinerja Organisasi, (Jakarta: PT. Rineka Cipta, 1999) 